\title{
Oestrogenic Endocrine Disruptors in the Placenta and the Fetus
}

\author{
Zi-Run Tang ${ }^{1,+}$, Xue-Ling $X u^{1,+}$, Shou-Long Deng ${ }^{2,3}{ }^{\mathbb{D}}$, Zheng-Xing Lian ${ }^{1}$ and Kun Yu ${ }^{1, *}$ \\ 1 Beijing Key Laboratory for Animal Genetic Improvement, National Engineering Laboratory for Animal \\ Breeding, Key Laboratory of Animal Genetics and Breeding of the Ministry of Agriculture, \\ College of Animal Science and Technology, China Agricultural University, Beijing 100193, China; \\ S20183040519@cau.edu.cn (Z.-R.T.); SY20183040655@cau.edu.cn (X.-L.X.); lianzhx@cau.edu.cn (Z.-X.L.) \\ 2 CAS Key Laboratory of Genome Sciences and Information, Beijing Institute of Genomics, \\ Chinese Academy of Sciences, Beijing 100101, China; popo84350746@163.com \\ 3 Institute of Laboratory Animal Sciences, Chinese Academy of Medical Sciences, Ministry of Health, \\ Beijing 100021, China \\ * Correspondence: young137@163.com \\ + These authors contributed equally to this work.
}

Received: 22 January 2020; Accepted: 20 February 2020; Published: 23 February 2020

\begin{abstract}
Endocrine disrupting chemicals (EDCs) are exogenous substances that interfere with the stability and regulation of the endocrine system of the body or its offspring. These substances are generally stable in chemical properties, not easy to be biodegraded, and can be enriched in organisms. In the past half century, EDCs have gradually entered the food chain, and these substances have been frequently found in maternal blood. Perinatal maternal hormone levels are unstable and vulnerable to EDCs. Some EDCs can affect embryonic development through the blood-fetal barrier and cause damage to the neuroendocrine system, liver function, and genital development. Some also effect cross-generational inheritance through epigenetic mechanisms. This article mainly elaborates the mechanism and detection methods of estrogenic endocrine disruptors, such as bisphenol A (BPA), organochlorine pesticides (OCPs), diethylstilbestrol (DES) and phthalates (PAEs), and their effects on placenta and fetal health in order to raise concerns about the proper use of products containing EDCs during pregnancy and provide a reference for human health.
\end{abstract}

Keywords: placenta; fetus; estrogenic endocrine disruptors

\section{Introduction}

An endocrine-disrupting compound is defined by the U.S. Environmental Protection Agency (EPA) as "an exogenous substance responsible for homeostasis, reproduction, and development that interferes with synthesis, secretion, transportation, metabolism, binding or elimination of natural blood-borne hormones in the body" [1]. In brief, an endocrine-disrupting substance is a compound that alters the hormonal and homeostatic systems. Molecules identified as endocrine disruptors are highly heterogeneous [2]. The sources of endocrine disrupting chemicals exposure are usually diverse and widely distributed in our daily life. EDCs are mostly man-made, including organochlorine pesticides (OCPs), plastics (e.g., bisphenol A (BPA)), cosmetic products, plasticizers (e.g., phthalates (PAEs)), and pharmaceutical agents (e.g., diethylstilbestrol (DES)) [3]. Natural chemicals found in the human diet (e.g., phytoestrogens, including genistein, daidzein, and coumestrol) also act as EDCs [2]. Since the late 1990s, the European Union (EU) has been working on policies related to EDCs that aim at phasing out endocrine disruptors in industrial chemicals, plant protection products, and biocides [4]. In 2017, the European Commission announced that it would start regulating consumer products, such as toys, cosmetics, and food packaging to minimize the exposure of EU citizens to endocrine 
disruptors [5]. EDCs may have adverse effects: they can interfere with significant life processes, such as sexual development, growth, and propagation, as well as the development of a living fetus [6].

The placenta is an important barrier for fetal protection during pregnancy. The placenta can produce human chorionic gonadotropin (hCG) and also participate in the exchange of gases, nutrients, and waste materials between mother and fetus. The human placenta develops primarily from trophoblast ectoderm cells outside the blastocyst. Cytotrophopblasts can be divided into villous cytotrophoblasts and extravillous trophoblasts (EVTs). Villous trophoblast cells continually fuse to form the human syncytiotrophoblasts [7]. EVTs invade the endometrium in the upper third of the myometrium, anchoring the fetus to the uterine wall. In addition, EVTs can invade the uterine spiral arteries (SAs), resulting in the remodeling of SAs, which provide the uterus with nutrient-rich blood [8]. Notably, the fetus may be indirectly affected by various EDCs through the placenta [9]. During this period, hormone and protein levels will change and balance as cells begin to grow and differentiate. When EDCs are transferred into the fetus through the placenta, the equilibrium state of the hormonal environment will be broken, due to the sensitivity of the immature fetus to EDCs, resulting in miscarriage, fetal growth retardation, and preeclampsia [10-12].

As shown in Figure 1, EDCs can enter pregnant women in different ways, e.g., through the food chain, the skin, or the respiratory tract. The mother may drink water or eat foods contaminated with EDCs. For example, phthalates are connected to polymer molecules through van der Waals forces and oxygen bonds in plastics products, which maintain relatively independent chemical properties of each other. With time, phthalates can slowly leak out of plastic products, into water, or food packaged in plastic [13]. Concentrations of BPA indoors have been estimated to be $1.46 \mathrm{mg} / \mathrm{kg}$ [14]. Mothers sometimes breathe dust in rooms with wallpaper or flooring containing EDCs or touch products made with BPA. A number of studies have revealed that some EDCs can be detected in the serum, amniotic fluid, breast milk, and urine of pregnant women $[15,16]$. Some of these may accumulate in placental tissues, and impair placental function, including plasticizers, organochlorine pesticides, personal care products, or naturally occurring EDCs found in plants. BPA exposure can significantly alter the methylation of imprinted genes in the mouse placenta, causing placental abnormality [17]. Clearly, the placenta is essential for the normal development and growth of the fetus. Subtle changes in placental function during the first trimester of pregnancy can change the fetal developmental trajectory, which affects various fetal physiological systems, such as the nervous system and immune system. Under this possible influence, the fetus is prone to disease, leading to congenital malformations [18]. Furthermore, chemical exposures to the mother may reach the fetus as a result of circulating blood through the placenta. Plasticizers such as phthalates and BPA have been reported to reach the fetus by blood circulating through the placenta because of the embryo's lack of adequate defense mechanisms [19]. Non-persistent organic pollutants (non-POPs) were also detected in meconium samples, meaning that there is a limit to the ability of the placenta to act as a barrier to these chemicals and indicating that they had already reached the developing fetus and been absorbed [20]. Even relatively modest concentrations, some lipid-soluble chemicals, such as organochlorine pesticides, are able to pass the placental barrier, through a simple mechanism of passive diffusion. One study showed that after crossing the placental barrier, organochlorine pesticides can also pass through the blood-brain barrier of a still immature fetus [21]. Fetal exposure to EDCs has been associated with physical developmental, and eventually may adversely compromise their reproductive and hormonal systems, as well as cause cancer [22]. Although several adverse effects of EDCs have been reported in the reproductive process, most are focused on child growth and maternal health. The damages on the health of the placenta and fetus are unclear. Here, we review several major estrogen endocrine disruptors in the body fluids of pregnant women, then dissect the influences of placenta and fetal health in order to effectively prevent diseases caused by EDCs in mothers and fetus. 
Sources of EDCs Body fluids EDCs Pregnancy and fetal disorders

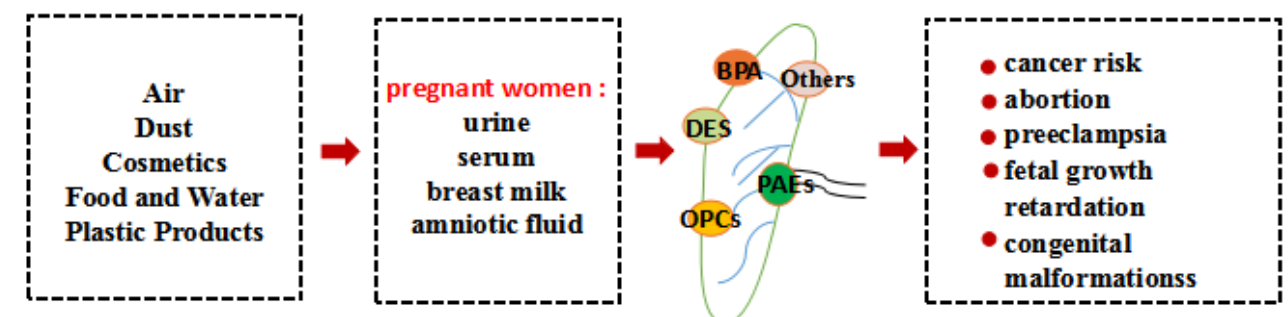

Figure 1. The transfer routes of several endocrine disrupting chemicals (EDCs) and the damages to pregnant women and fetuses. Pregnant women are exposed to EDCs from the air, food, and products which damage the placenta through body fluids, thereby causing health problems.

\section{Detection Methods}

Pregnant women are a unique population who are exposed to endocrine disruptors during pregnancy that can affect the baby through body fluids. Liquids such as urine, maternal milk, serum, and amniotic fluid are currently the most commonly used substances to assess the EDCs in the body [16,23]. Its widespread use has led to the detection of BPA in low doses in pregnant women. The measurement of organic pollutants (POPs) in mothers is usually via breast milk or serum samples [24]. Since the phthalates are rapidly metabolized into monoester metabolites in the body and then excreted in the urine, monitoring urinary phthalate metabolites is a commonly used method to investigate pregnant women's exposure to phthalates $[25,26]$. Phytoestrogens, such as daidzein and genistein, have been found in the serum and amniotic fluid of pregnant women [27]. Experiments have shown that genistein could be transplanted in human and rat placentas [28,29]. Scientists are continuously improving analytical methodologies in order to be able to identify environmental endocrine disruptors in pregnant women [30]. Among them, mass spectrometry (MS) has the characteristics of high sensitivity and strong qualitative ability. However, for some compounds, such as alkylphenols, synthetic sterols, and bisphenol A, mass spectrometry requires sample preparation and cleaning and derivatization steps, which makes this method inefficient for detecting analyses. Furthermore, gas chromatography (GC) has a highly effective separation effect for each component in the mixture. With the development of science and technology, the GC combines this with MS to increase the reliability in the detection of environmental endocrine disruptors. Therefore, gas chromatography-mass spectrometry (GC-MS) technology has been greatly developed. In addition, liquid chromatography-mass spectrometry (LC-MS) has also begun to be applied. High performance liquid chromatography (HPLC) has a wide range of applications and high sensitivity, and the processed samples are not damaged and easy to recover. However, HPLC is not as sensitive as gas chromatography. Table 1 lists the detection methods of some EDCs in the body fluids of pregnant women. 
Table 1. Detection methods of some endocrine disruptors in maternal body fluids.

\begin{tabular}{|c|c|c|c|c|c|c|}
\hline EDCs Exposure & Compound & Area & $\begin{array}{l}\text { Measurement } \\
\text { Method }\end{array}$ & Body Fluid & $\begin{array}{l}\text { Mean } \pm \text { SD } \\
\text { or Range }\end{array}$ & Reference \\
\hline \multirow{4}{*}{ Bisphenol A } & BPA & Germany & $\begin{array}{c}\text { Chemical } \\
\text { derivatization- } \\
\text { GC-MS }\end{array}$ & Maternal plasma & $0.3-18.9 \mathrm{ng} / \mathrm{mL}$ & [31] \\
\hline & BPA & Germany & GC-MS & Fetal plasma & $0.2-9.2 \mathrm{ng} / \mathrm{mL}$ & [31] \\
\hline & BPA & Japan & $\begin{array}{c}\text { Enzyme-linked } \\
\text { immunosorbent } \\
\text { assay }\end{array}$ & Amniotic fluids & $0-8.38 \mathrm{ng} / \mathrm{mL}$ & {$[32,33]$} \\
\hline & BPA & Germany & GC-MS & The placental tissue & $1-104.4 \mathrm{ng} / \mathrm{g}$ & {$[31,34]$} \\
\hline \multirow{4}{*}{$\begin{array}{l}\text { Organochlorine } \\
\text { pesticides }\end{array}$} & $\begin{array}{l}\alpha \text {-hexachlorocyclohexane } \\
(\alpha-\mathrm{HCH})\end{array}$ & $\begin{array}{c}\text { The Los } \\
\text { Angeles area }\end{array}$ & GC-MS & Amniotic fluids & $0.15 \pm 0.06 \mathrm{ng} / \mathrm{mL}$ & [35] \\
\hline & $\begin{array}{l}\mathrm{p}, \mathrm{p}^{\prime} \text {-Dichlorodiphenyldichloroethylene } \\
\text { (p,p'-DDE) }\end{array}$ & $\begin{array}{c}\text { The Los } \\
\text { Angeles area }\end{array}$ & GC-MS & Amniotic fluids & $0.21 \pm 0.18 \mathrm{ng} / \mathrm{mL}$ & [35] \\
\hline & $\begin{array}{l}\mathrm{p}, \mathrm{p}^{\prime} \text {-Dichloro-diphenyl-trichloroethane } \\
\qquad\left(\mathrm{p}, \mathrm{p}^{\prime} \text {-DDT }\right)\end{array}$ & Mexico & $\begin{array}{c}\text { Dual column } \\
\text { gas } \\
\text { chromatograph- } \\
\text { electron } \\
\text { capture } \\
\text { detector } \\
\end{array}$ & Serum & 676 ng/g-lipid & [36] \\
\hline & $\mathrm{p}, \mathrm{p}^{\prime}-\mathrm{DDE}$ & Mexico & $\begin{array}{l}\text { Dual column } \\
\text { gas } \\
\text { chromatograph- } \\
\text { electron } \\
\text { capture } \\
\text { detector }\end{array}$ & Serum & 4,843 ng/g-lipid & [36] \\
\hline \multirow{4}{*}{ Phthalates } & $\begin{array}{l}\text { Methylerythritol cyclodiphosphate } \\
\text { (MECPP) }\end{array}$ & America & $\begin{array}{l}\text { Isotope-dilution } \\
\text { HPLC/MS/MS }\end{array}$ & Breast milk & $0.1-0.4 \mu \mathrm{g} / \mathrm{L}$ & [37] \\
\hline & MEHHP & America & HPLC/MS/MS & Breast milk & $0.2-0.3 \mu \mathrm{g} / \mathrm{L}$ & [37] \\
\hline & $\begin{array}{l}\text { Mono-ethyl phthalate } \\
\text { (MEP) }\end{array}$ & Canada & LC-MS/MS & Urine & $32.02 \mu \mathrm{g} / \mathrm{L}$ & [38] \\
\hline & $\begin{array}{l}\text { Mono-n-butyl phthalate } \\
\text { (MnBP) }\end{array}$ & Canada & LC-MS / MS & Urine & $11.59 \mu \mathrm{g} / \mathrm{L}$ & [38] \\
\hline Diethylstilbestrol & DES & China & $\begin{array}{l}\text { HPLC with } \\
\text { diode array } \\
\text { detection }\end{array}$ & Urine & $1-200 \mu \mathrm{g} / \mathrm{L}$ & [39] \\
\hline \multirow{4}{*}{ Phytoestrogens } & Daidzein & America & GC/MS & Amniotic fluid & $1.44-5.52 \mathrm{ng} / \mathrm{mL}$ & [40] \\
\hline & Genistein & America & GC/MS & Amniotic fluid & $1.69-6.54 \mathrm{ng} / \mathrm{mL}$ & [40] \\
\hline & Daidzein & America & $\begin{array}{l}\text { Ultra-performance } \\
\text { liquid } \\
\text { chromatography- } \\
\text { MS/MS } \\
\text { (UPLC-MS/MS) }\end{array}$ & Urine & $0.11 \mu \mathrm{g} / \mathrm{L}$ & [41] \\
\hline & Genistein & America & UPLC-MS/MS & Urine & $0.59 \mu \mathrm{g} / \mathrm{L}$ & [41] \\
\hline
\end{tabular}

\section{Endocrine Disrupting Chemicals}

\subsection{Bisphenol A}

BPA is an industrial chemical that has been used to make certain plastics and epoxy resins. More specifically, food packaging bottles are mostly made of polycarbonate plastics, while epoxy resins are extensively used in composite materials, such as beverage cans, bottle tops, and water supply lines. In addition, BPA is also found in other daily items, such as thermal printing papers, medical equipment, coating powders, sunglasses, baby bottles, and sippy cups [42]. It is a colorless solid, poorly soluble in water, but soluble in organic solvents, such as ether, acetone, and alcohol. In our life, we are exposed to BPA toxicity directly through foods packaged with BPA products. Children

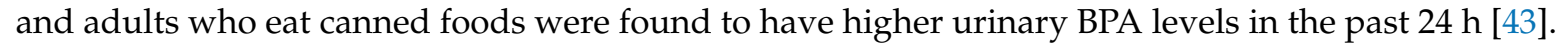
On the other hand, we are indirectly exposed to BPA contamination through the environment [44].

In fact, exposure to BPA during early embryonic development can lead to numerous development abnormalities. According to Figure 2, interfering with placental production of hCG may be a means by which BPA affects the fetus. The roles of hCG during pregnancy include the promotion of the invasion and differentiation of trophoblast cells, the growth of the placenta, and angiogenesis in the uterine vasculature. BPA can directly act on the placenta, leading to abnormal labyrinthine development of trophoblast cells, which can severely affect the hCG secretion of the early trimester 
trophoblast and increase cell apoptosis [45]. However, some experiments have shown that BPA increased the levels of anti-apoptotic proteins like Bcl-2 and Hsp70, and decreased HIF-1 $\alpha$ levels in BeWo cells, reducing apoptosis [46]. Furthermore, a low dose of BPA (1-1000 nM) could activate the ERK signaling pathway to downregulate the expression of CYP11A1 and CYP19, decrease placental aromatase activity, and cause the estradiol and progesterone production to decrease [47]. A lack of hormones may contribute to placental insufficiency and pregnancy failure. BPA also inhibits the expression of Wnt $2 / \beta$-catenin and increased DNA methylation of Wnt2 in its promoter region, thereby mediating epigenetic modification [48]. These findings suggest a potential mechanism by which BPA causes reproductive toxicity. The possible mechanisms of BPA in the placenta are complicated and worth exploring.

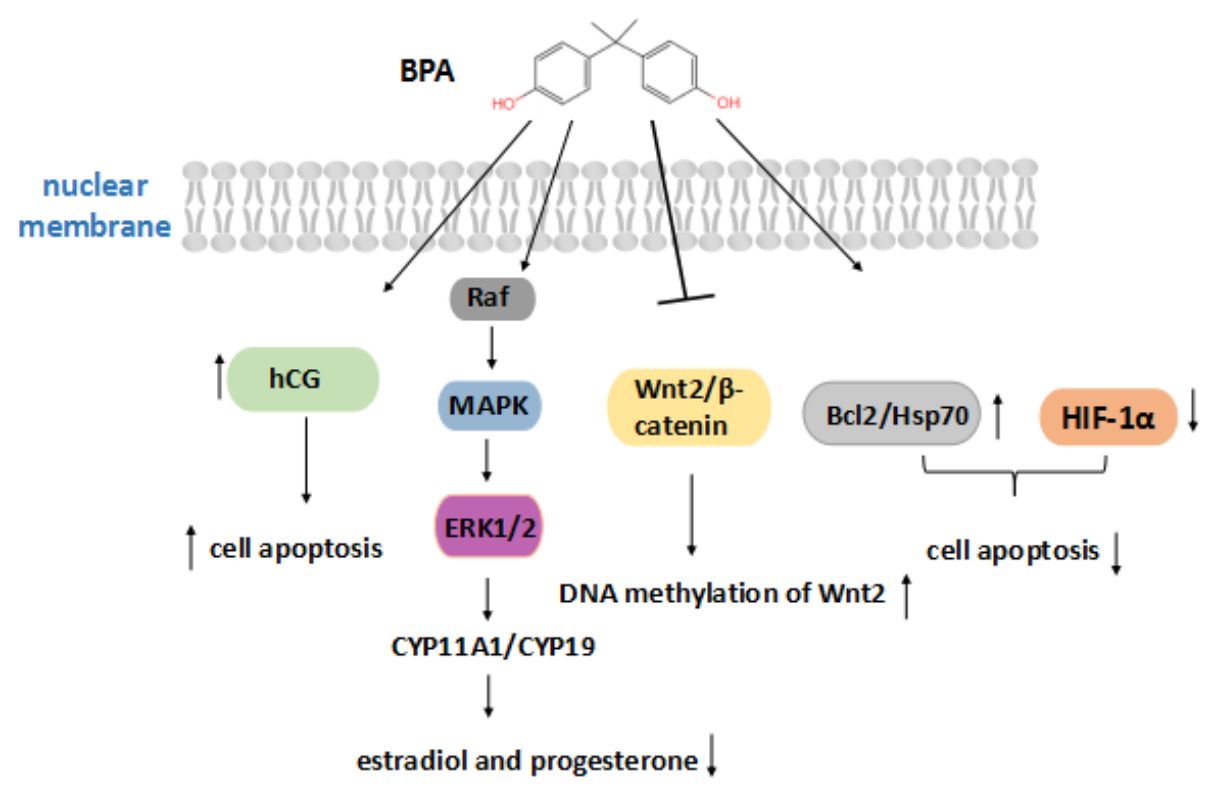

Figure 2. BPA action on placental growth. The arrow facing up indicates an increase, and the arrow facing down indicates a decrease, due to BPA. Bisphenol A increases the secretion of hCG and cell apoptosis, or activates the ERK signaling pathway to reduce estradiol and progesterone hormones, and also inhibits the expression of Wnt $2 / \beta$-catenin. On the other hand, BPA can increase the levels of Bcl-2 and Hsp70 and reduce the level of HIF-1 $\alpha$ to reduce apoptosis.

Adverse effects of low doses of BPA exposure during pregnancy on the female reproductive system have been reported [49]. In addition, BPA may enter the placenta through the mother, so mammals' prenatal exposure to low concentrations of BPA can adversely affect the developing fetus. When placental cells were exposed to seven different concentrations of BPA for one day, researchers discovered that damage to the cell membrane was 1.3 to 1.7 times higher in placenta cells than untreated cells. Such exposure can lead to adverse pregnancy outcomes such as premature birth, preeclampsia, and pregnancy loss [50]. A study demonstrated for the first time that exposure of BeWo cells to BPA at a concentration of $50 \mathrm{nM}$ increased the gene expression of three human endogenous retrovirus capsules and related syncytia proteins, thereby affecting the fusion of trophoblast cells and endocrine activity [51]. As observed in mice, over-promotion of syncytial trophoblast may be detrimental to placental mammals, unbalancing the trophoblast lineage during development, and then affecting fetal growth. Furthermore, BPA can significantly induce the secretion of $\beta$-hCG, enhancing the endocrine function of the placenta, and inhibiting trophoblast invasion [52]. In addition, some findings demonstrated that exposure to BPA can alter the expression of the imprinted genes, leading to abnormal placental development, and also reduce DNA methylation in the mouse placenta to perturb fetal health via epigenetic changes [53]. Maternal exposure to BPA in early pregnancy predicts DNA methylation in newborns, which is associated with gene expression levels related to growth and 
metabolism. And DNA methylation has a potential impact on disease susceptibility in the fetus [54]. Female mice exposure to BPA during early pregnancy can result in impaired remodeling of uterine SAs, which has a negative effect on vasoconstrictive ability and blood flow velocity, limiting the blood supply to the placenta and fetus. The insufficient remodeling of uterine SAs caused by BPA exposure not only reduces the weight of placenta but also affects fetal growth and provokes intrauterine growth retardation (IUGR) in the fetus [55].

Newborns are susceptible to BPA because of an immature liver function and underdeveloped glucose acidification movement. BPA acts as an androgen receptor (AR) antagonist to inhibit dihydrotestosterone (DHT) induced transcriptional activity, thereby affecting the development and function of the male reproductive systems. Pregnant mice exposed to $10 \mu \mathrm{g} / \mathrm{kg}$ BPA per day will lead to abnormal development of the prostate and urethra in male fetuses and permanently disrupt cellular control systems and increase the risk of prostate cancer in adult male mammals [56,57]. Subsequently, in adulthood, the number of prostatic androgen receptors per cell doubled, causing an enlarged prostate [58]. The developing brain is particularly sensitive to BPA; rats' exposure to a dosage less than $50 \mu \mathrm{g} / \mathrm{kg}$ BPA of the human acceptable daily intake level can affect the sexual differentiation of the neural structures and behavior of the fetus [59]. BPA alters intracellular molecular mechanisms that may cause breast cancer by binding to estrogen-related receptors (ERRs) or G protein-coupled receptors (GPERs). Fetal exposure to low doses of BPA has long-term effects, increasing the risk of breast cancer in adulthood [60].

\subsection{Organochlorine Pesticides}

Organochlorine pesticides (OCPs) are a class of organic compounds containing carbon, hydrogen, and chlorine, which are used to control insects, weeds, and fungus. Statistically, in the use of different pesticides, $40 \%$ of all pesticides used belong to the organochlorine class of chemicals. This is a large group of chlorinated hydrocarbons that includes dichlorodiphenyltrichloroethane (DDT) and its metabolites, hexachlorobenzene HCB, lindane, and dieldrin [61]. DDT is widely used in agriculture but is now forbidden in many countries. OCPs have the features of low water solubility, stable chemical properties, and an ability to adsorb organic materials in soil; thus, the use of a large number of pesticides in agricultural production has led to the aggravation of soil, water, and air pollution. OCPs are gradually transmitted to fish and higher animals such as humans through the food chain, therefore, many aquatic and terrestrial species are seriously affected [62,63].

Organic chloride pollutants have a high affinity with hydrocarbon (Ah) receptors [64]. The combination intensely induced cytochrome P4501A1 (CYP1A1) gene encoding the cytochrome P-450 1A1 enzymes involves organochlorines' metabolism [65]. Organochlorine metabolism in the body can produce a large number of reactive oxygen species, which the anti-oxidant system fails to eliminate, thereby breaking DNA strands and affecting mitochondrial function. CYP1A1 is involved in metabolism in the human placenta; abnormal expression of this enzyme may disrupt the placental detoxification machinery $[66,67]$.

It is of concern that organochlorine pesticides often badly affect non-target species, such as human beings and animals, when applied to their target organisms. Organochlorine pesticides have a lipophilic nature that can easily dissolve in human and animal adipose tissue. During pregnancy, they can be mobilized and enter maternal blood circulation and reach the placenta [68]. These compounds can interfere with the functions of the placenta, such as the production and release of hormones and enzymes, the transportation of nutrients, and the generation of waste, and then disrupt fetal development and the last stage of placental life [69]. A result of research showed that oxidative stress caused by organochlorine pesticides can result in preterm deliveries [70]. Pathak et al. have observed that the higher concentration of $\beta-\mathrm{HCH}$ in umbilical cord blood increased the risk of premature birth. Furthermore, they also noticed that the serum level of $\gamma-\mathrm{HCH}$ was positively correlated with female habitual miscarriage [71,72]. Exposure to organic pollutants during pregnancy increased $p, p^{\prime}-\mathrm{DDE}$ concentrations in maternal blood, and the levels of $\mathrm{p}, \mathrm{p}^{\prime}$-DDE transferred from maternal blood to breast 
milk and umbilical cord blood was also increased. It may have toxic effects on breast and placental functions, such as vascular lesions and endothelial degeneration [73]. In the epidemiological model, the levels of maternal organochlorine pesticides were associated with hyper-methylation of placental genes, and high levels of $\mathrm{p}, \mathrm{p}^{\prime}$-DDT are significantly associated with insulin-like growth factor 2 (IGF2), which may also explain fetal growth restriction [74]. Dewan et al. found OCP levels in placentas were negatively correlated with chest circumference, head circumference, and body mass index in newborns [75].

It was reported that early exposure to organochlorine compounds with endocrine-disruption activity may interfere with neonatal thyroid hormone status [76]. OCPs in maternal blood can be transported through the placenta and affect neonatal thyroid hormone levels [77]. By investigating the thyroid hormone situation of 15-year-old children in rural areas of Brazil with severe OPC exposure, it was found that the increase of total triiodothyronine (T3) levels in serum was related to the high concentration of OCPs, which had adverse impacts on children's growth [78]. Moreover, maternal exposure to OCPs in early pregnancy contributed adversely to sperm density and activity in male fetuses, resulting in a decline in male fertility [79]. OCPs act as endocrine-disruptor chemicals by disrupting the physiologic function of endogenous hormones and thus possibly increasing cancer risk. Kumar et al. revealed a significant positive correlation between the risk of prostate cancer and serum levels of OCPs, especially the high level of $\beta-\mathrm{HCH}, \gamma-\mathrm{HCH}$, and p,p'-DDE [80].

\subsection{Diethylstilbestrol}

Diethylstilbestrol, a synthetic non-steroidal estrogen substance, produces the pharmacological and therapeutic effects of natural estradiol but is five times more potent [81]. DES can promote the normal development of the female reproductive system, endometrial hyperplasia, and vaginal epithelial keratinization and improve the sensitivity of the uterus to oxytocin. When low doses of DES are used, it stimulates the secretion of anterior pituitary gonadotropins and prolactin. Conversely, the use of high doses of DES will inhibit this effect. In addition, DES also has an anti-androgenic effect and binds to estrogen receptors (ERs) or progesterone receptors (PRs), which has adverse effects on reproduction. Therefore, in the 1970s, DES was widely used as an estrogen-like drug for oral contraceptives, preventing miscarriage, and replacing hormones for clinical treatment. However, in 1971, research found for the first time that vaginal malignancies in adolescent girls were partially attributed to DES exposure during fetal development [82]. Subsequent studies have shown that the approval of DES for clinical treatment was a serious mistake, which has resulted in a series of irreparable consequences [83].

Several ongoing studies have compared the health status of women exposed to DES and unexposed controls of the corresponding age. These studies found that the incidences of infertility, spontaneous miscarriage, and premature delivery, pregnancy loss in the second trimester, ectopic pregnancy, pre-eclampsia, and stillbirth in women with DES exposure were much higher than those in the control group. It is worth noting that the risk of breast cancer in women experiencing DES exposure is also increasing [84-87]. As we have mentioned before, exposure to EDCs may lead to enormous and unrecoverable damage to the fetus. Daughters of DES-treated women were affected by DES in the uterus, which may cause vaginal adenoma, corpus luteum deficiency, polycystic ovary induction, and other reproductive abnormalities [88-90]. Sons of DES-treated women has a higher rate of genital tract abnormalities [91].

DES affects mothers and their daughters/sons, not only at a particular physiological stage, but also with a long-term impact [2]. Studies have shown that the presence of DES has affected multiple signaling pathways in the body, but this is not yet fully clarified. It is now commonly believed that early DES exposure causes its effects by genetic and epigenetic alterations, not by changes in gene mutation [92]. Neonatal exposure to DES can cause extensive changes in gene expression that persist into adulthood. Through molecular studies, many of the changes caused by DES is the control of reproductive tract development by inhibiting HOX and Wnt genes, and the DES induced uterine 
malformations may be due to the downregulation of HOXA11 gene [93,94]. Due to exposure to DES may cause DNA methylation, the fetal genome is allowed to encode multiple defects, which may not be expressed before a certain period of time (puberty, for example) [95]. Studies have shown that microRNA levels may change due to the effects of DES, and microRNA-mediated upregulation of Fas and its ligands leads to increased autophagy and apoptosis [96].

\subsection{Phthalates}

Phthalates (PAEs) are industrial chemicals that are widely used as plasticizers to increase the flexibility and softness of plastic and are also used as stabilizing agents. A wide variety of consumer products are made with phthalates, including personal care products, automotive parts, children's toys, food packaging, and building materials [97]. In addition, some medical equipment also contains phthalates. As an endocrine disruptor, phthalates have been listed as a major environmental estrogen with a function similar to artificial hormones and are the most widespread pollutant. Studies of phthalates both in vivo and in vitro have shown that they have a higher level of biological activity and toxicity when they are metabolized as monoesters [98].

Phthalates are important synthetic chemicals which can induce toxicity, and the mechanism of the toxicity caused by phthalates needs to be further understood. Phthalates increase reactive oxygen species to alter the expression and activity of antioxidant enzymes that result in DNA damage [99]. As detailed in Figure 3, monoethylhexyl phthalate (MEHP), the reactive metabolite of phthalates, activates peroxisome proliferator-activated receptor (PPAR), and then combines with retinoid $X$ receptor (RXR) [100]. Subsequently, they are transported to the nucleus, inducing gene expression and increasing oxidative stress. Oxidative DNA damage could inhibit the binding of methyl-CpG binding proteins $(\mathrm{MeCP})$ and lead to epigenetic changes in chromatin organization [101]. MEHP exposure, inhibiting trophoblast invasion by activating PPAR $\gamma$, is the most critical mechanism for early pregnancy loss [102]. Furthermore, placental ErbB signaling is one of the most important signaling pathways in response to DNA methylation and gene expression induced by phthalate exposure. This pathway works through tyrosine kinases, including two critical members, epidermal growth factor (EGF), and epidermal growth factor receptor (EGFR). The EGF signaling pathway activates numerous intercellular pathways that stimulate placental growth and function, including regulation of trophoblast cell proliferation, differentiation, and invasion [103,104]. Exposure to phthalates in early pregnancy alters placental transcriptome as a methylation change of critical placental DNA such as Insulin Growth Factor 2 (IGF2) [105]. This suggests that the pathway may be a potential target for endocrine disruption by phthalates. 


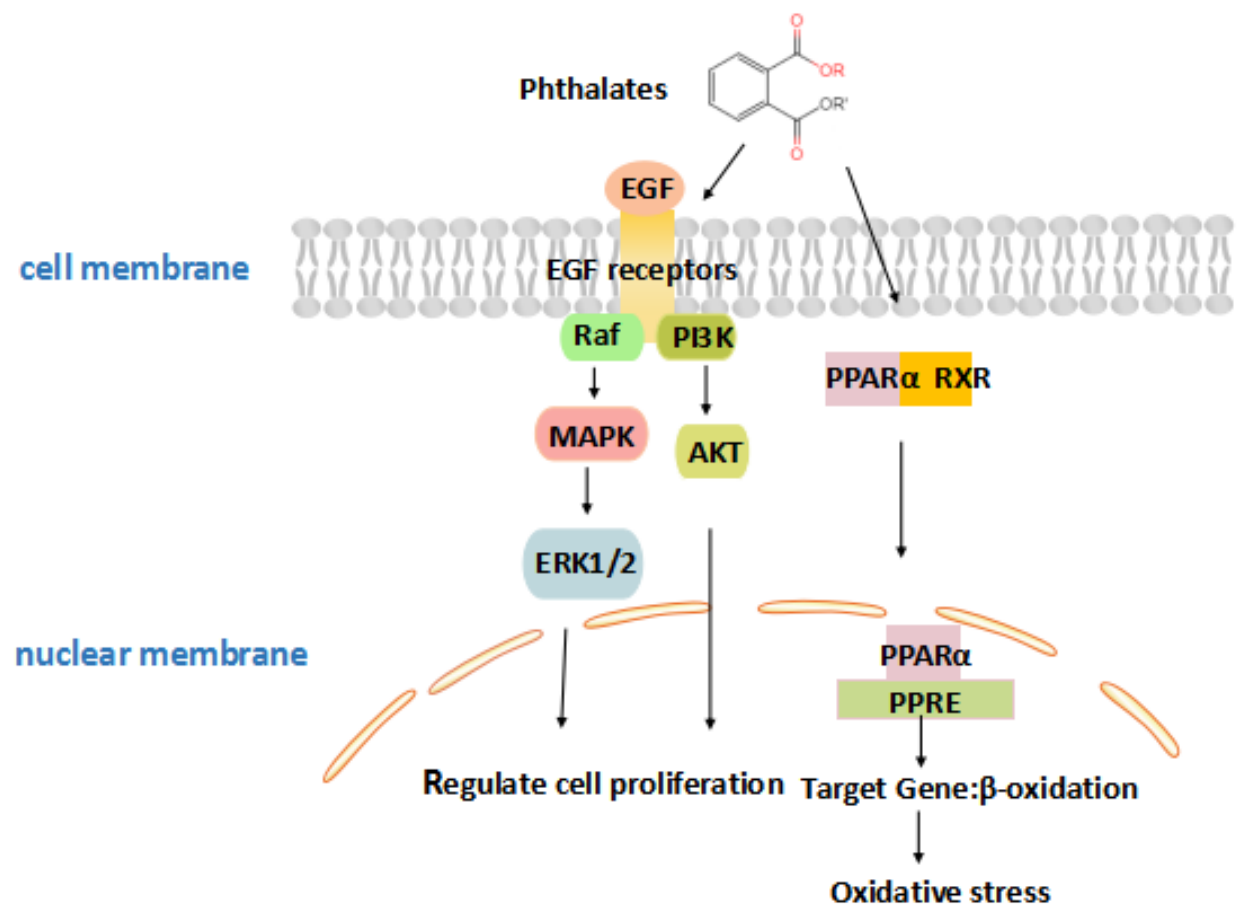

Figure 3. A schematic illustrating the effects of phthalates on placental growth. Phthalates activate peroxisome proliferator-activated receptor (PPAR), which is associated with placental development, or modulate the combination of epidermal growth factor (EGF) and epidermal growth factor receptor (EGFR), and activate phosphatidylinositol 3-kinase/protein kinase B (PI3K/Akt) and signal-regulated kinase (ERK) signaling pathways, then regulate proliferation, survival, and differentiation in the body.

Owing to the wide application of PAEs, problems such as preterm birth, ovarian cancer, and recurrent pregnancy loss are becoming increasingly prominent [106,107]. A previous study examined urine samples of human chorionic gonadotropin to investigate a possible link between phthalate exposure and early miscarriage. Results showed that exposure to high doses of MEHP was associated with early miscarriage compared to low MEHP exposure [108]. Jukic et al. revealed that pregnant females' exposure to excess di(2-ethylhexyl) phthalate (DEHP) was believed to increase the risk of developing early embryo loss [109]. MEHP changed the synthesis of lipidosomes in the JEG-3 human trophoblast cells leading to lipid imbalance [110]. Furthermore, Grindler et al. investigated the methylation changes of 39 genes in first trimester placenta and found that most of the changes were negative [105].

Phthalates can cross the placental barrier as a result of continuous exposure during pregnancy, with profoundly negative consequences for the future health of infants, by increasing the risk of developing defects such as low birth weight, cardiovascular diseases, cryptorchidism, and cancer later in life $[111,112]$. The metabolites of DEHP have been detected by mass spectrometry in amniotic fluid. The results showed that the metabolism may be associated with cryptorchidism and hypospadias in male fetuses [113].

\subsection{Phytoestrogens}

Phytoestrogens are compounds that have weak estrogenic effects in plants and are known to be present in several different types of food, such as grains, beans, fruits, vegetables, and, in particular, many soy products $[114,115]$. The three major classes of phytoestrogens in the human body are lignan, isoflavones (daidzein, genistein, and glycitein), and coumestans (coumestrol). Phytoestrogens are a plant component with biological activity similar to animal estrogen, with a wide range of effects on hormone-related diseases, and they exert a weak estrogen-like effect by binding to the ER with low affinity. ERs are present in different tissues, including the reproductive tract, bones, 
placenta, and mammary gland, suggesting that phytoestrogens may play a tissue-specific hormonal role $[116,117]$. ER $\alpha$ is perceived to promote cell growth, whereas ER $\beta$ does the opposite, mainly promoting apoptosis [118]. Different phytoestrogens have different affinities for binding to ERs. Coumestrol has the highest affinity, which is 10 to 20 times lower than estradiol, followed by genistein. The same phytoestrogens have a different affinity for ER $\alpha$ and ER $\beta$. The affinity of apigenin for ER $\beta$ is higher than that of ER $\alpha$. The affinity of coumestrol and genistein for ER $\beta$ is higher than for ER $\alpha$.

For example, genistein is a major active factor and the most effective functional component of soy isoflavones, with a variety of physiological functions. The genistein can alter the level of IGF-1 and placenta growth factor (PGF), and thus alter the normal growth and development of the placenta and the fetus [119]. Genistein and daidzein could inhibit the production of hCG, and the production of hCG was significantly decreased in the trophoblast cells treated with genistein and daidzein [120]. Genistein and daidzein are type of phytoestrogens, so exposure to these estrogen-like compounds during sensitive periods of growth and development may have the capacity to alter the function of the reproductive system, thereby affecting fetal health.

\section{Concluding Remarks}

This review details the characteristics, mechanisms, validation methods, and influences on the placenta and the fetus of several kinds of endocrine disrupting chemicals, including bisphenol A, organochlorine pesticides, diethylstilbestrol, and phthalates. Today, there are numerous ways for people to directly or indirectly come in contact with EDCs. The negative impact of the toxicity of EDCs on human health is a serious problem that must be addressed. Some EDCs can cross the placental barrier and accumulate in the placenta. As the most important and significant development stage of life, the fetus should be protected from all toxic and harmful substances. Further research on EDCs is ongoing, but the unknown mechanisms of EDCs' functions remain a challenge for scientists to discover and understand. The effects of EDCs on the early placenta may raise concerns about the proper use of products containing EDCs during pregnancy and encourage early preventative measures. We hope this brief review provides a reference for human health and disease.

Author Contributions: S.-L.D., K.Y., X.-L.X., Z.-X.L., and Z.-R.T. wrote the paper. All authors have read and agreed to the published version of the manuscript.

Funding: This work was supported by grants from the National Transgenic Creature Breeding Project (2016zx08008-003).

Conflicts of Interest: The authors declare no conflict of interest.

\section{References}

1. Kavlock, R.J.; Daston, G.P.; DeRosa, C.; Fenner-Crisp, P.; Gray, L.E.; Kaattari, S.; Lucier, G.; Luster, M.; Mac, M.J.; Maczka, C.; et al. Research needs for the risk assessment of health and environmental effects of endocrine disruptors: A report of the U.S. EPA-sponsored workshop. Environ. Health Perspect. 1996, 104, 715-740.

2. Diamanti-Kandarakis, E.; Bourguignon, J.; Giudice, L.C.; Hauser, R.; Prins, G.S.; Soto, A.M.; Zoeller, R.T.; Gore, A.C. Endocrine-disrupting chemicals: An Endocrine Society scientific statement. Endocr. Rev. 2009, 30, 293-342. [CrossRef]

3. Monneret, C. What is an endocrine disruptor? CR Biol. 2017, 340, 403-405. [CrossRef]

4. Commission of the European Communities. Community Strategy for Endocrine Disrupters: A Range of Substances Suspected of Interfering with the Hormone Systems of Humans and Wildlife; COM (1999) 706 Final; Commission of the European Communities: Brussels, Belgium, 1999.

5. Candidate List of Substances of Very High Concern for Authorisation; European Communities: Brussels, Belgium, 2017.

6. Kabir, E.R.; Rahman, M.S.; Rahman, I. A review on endocrine disruptors and their possible impacts on human health. Environ. Toxicol. Pharmacol. 2015, 40, 241-258. [CrossRef] [PubMed] 
7. Pollheimer, J.; Vondra, S.; Baltayeva, J.; Beristain, A.G.; Knofler, M. Regulation of Placental Extravillous Trophoblasts by the Maternal Uterine Environment. Front. Immunol. 2018, 9, 2597. [CrossRef] [PubMed]

8. Saghian, R.; Bogle, G.; James, J.L.; Clark, A.R. Establishment of maternal blood supply to the placenta: Insights into plugging, unplugging and trophoblast behaviour from an agent-based model. Interface Focus 2019, 9, 20190019. [CrossRef] [PubMed]

9. Murphy, V.E.; Smith, R.; Giles, W.B.; Clifton, V.L. Endocrine regulation of human fetal growth: The role of the mother, placenta, and fetus. Endocr. Rev. 2006, 27, 141-169. [CrossRef]

10. Lauritzen, H.B.; Larose, T.L.; Oien, T.; Sandanger, T.M.; Odland, J.O.; van de Bor, M.; Jacobsen, G.W. Maternal serum levels of perfluoroalkyl substances and organochlorines and indices of fetal growth: A Scandinavian case-cohort study. Pediatr. Res. 2017, 81, 33-42. [CrossRef]

11. Geer, L.A.; Pycke, B.F.G.; Waxenbaum, J.; Sherer, D.M.; Abulafia, O.; Halden, R.U. Association of birth outcomes with fetal exposure to parabens, triclosan and triclocarban in an immigrant population in Brooklyn, New York. J. Hazard. Mater. 2017, 323, 177-183. [CrossRef]

12. Ye, Y.; Zhou, Q.; Feng, L.; Wu, J.; Xiong, Y.; Li, X. Maternal serum bisphenol A levels and risk of pre-eclampsia: A nested case-control study. Eur. J. Public Health 2017, 27, 1102-1107. [CrossRef] [PubMed]

13. Ma, T.T.; Christie, P.; Luo, Y.M.; Teng, Y. Phthalate esters contamination in soil and plants on agricultural land near an electronic waste recycling site. Environ. Geochem. Health 2013, 35, 465-476. [CrossRef] [PubMed]

14. Michalowicz, J. Bisphenol A-sources, toxicity and biotransformation. Environ. Toxicol. Phar. 2014, 37, 738-758. [CrossRef] [PubMed]

15. Maitre, L.; Robinson, O.; Martinez, D.; Toledano, M.B.; Ibarluzea, J.; Marina, L.S.; Sunyer, J.; Villanueva, C.M.; Keun, H.C.; Vrijheid, M.; et al. Urine Metabolic Signatures of Multiple Environmental Pollutants in Pregnant Women: An Exposome Approach. Environ. Sci. Technol. 2018, 52, 13469-13480. [CrossRef]

16. Shekhar, S.; Sood, S.; Showkat, S.; Lite, C.; Chandrasekhar, A.; Vairamani, M.; Barathi, S.; Santosh, W. Detection of phenolic endocrine disrupting chemicals (EDCs) from maternal blood plasma and amniotic fluid in Indian population. Gen. Comp. Endocr. 2017, 241, 100-107. [CrossRef]

17. Susiarjo, M.; Sasson, I.; Mesaros, C.; Bartolomei, M.S. Bisphenol a exposure disrupts genomic imprinting in the mouse. PLoS Genet. 2013, 9, e1003401. [CrossRef]

18. Skakkebaek, N.E.; Toppari, J.; Soder, O.; Gordon, C.M.; Divall, S.; Draznin, M. The exposure of fetuses and children to endocrine disrupting chemicals: A European Society for Paediatric Endocrinology (ESPE) and Pediatric Endocrine Society (PES) call to action statement. J. Clin. Endocrinol. Metab. 2011, 96, 3056-3058. [CrossRef]

19. Perez-Albaladejo, E.; Fernandes, D.; Lacorte, S.; Porte, C. Comparative toxicity, oxidative stress and endocrine disruption potential of plasticizers in JEG-3 human placental cells. Toxicol. Vitr. 2017, 38, 41-48. [CrossRef]

20. Li, L.; Chen, L.; Meng, X.; Chen, B.; Chen, S.; Zhao, Y.; Zhao, L.; Liang, Y.; Zhang, Y. Exposure levels of environmental endocrine disruptors in mother-newborn pairs in China and their placental transfer characteristics. PLoS ONE 2013, 8, e62526. [CrossRef]

21. Roncati, L.; Piscioli, F.; Pusiol, T. The endocrine disruptors among the environmental risk factors for stillbirth. Sci. Total Environ. 2016, 563-564, 1086-1087. [CrossRef]

22. Feeley, M.; Brouwer, A. Health risks to infants from exposure to PCBs, PCDDs and PCDFs. Food Addit. Contam. 2000, 17, 325-333. [CrossRef] [PubMed]

23. Dusza, H.M.; Janssen, E.; Kanda, R.; Legler, J. Method Development for Effect-Directed Analysis of Endocrine Disrupting Compounds in Human Amniotic Fluid. Environ. Sci. Technol. 2019, 53, 14649-14659. [CrossRef] [PubMed]

24. Mannetje, A.T.; Coakley, J.; Mueller, J.F.; Harden, F.; Toms, L.; Douwes, J. Partitioning of persistent organic pollutants (POPs) between human serum and breast milk: A literature review. Chemosphere 2012, 89, 911-918. [CrossRef] [PubMed]

25. Frederiksen, H.; Kranich, S.K.; Jorgensen, N.; Taboureau, O.; Petersen, J.H.; Andersson, A. Temporal variability in urinary phthalate metabolite excretion based on spot, morning, and 24-h urine samples: Considerations for epidemiological studies. Environ. Sci. Technol. 2013, 47, 958-967. [CrossRef] [PubMed]

26. Krais, A.M.; Andersen, C.; Eriksson, A.C.; Johnsson, E.; Nielsen, J.; Pagels, J.; Gudmundsson, A.; Lindh, C.H.; Wierzbicka, A. Excretion of Urinary Metabolites of the Phthalate Esters DEP and DEHP in 16Volunteers after Inhalation and Dermal Exposure. Int. J. Environ. Res. Publ. Health 2018, 15, 2514. [CrossRef] [PubMed] 
27. Jarrell, J.; Foster, W.G.; Kinniburgh, D.W. Phytoestrogens in human pregnancy. Obstet. Gynecol. Int. 2012, 2012, 850313. [CrossRef]

28. Soucy, N.V.; Parkinson, H.D.; Sochaski, M.A.; Borghoff, S.J. Kinetics of genistein and its conjugated metabolites in pregnant Sprague-Dawleyrats following single and repeated genistein administration. Toxicol. Sci. Off. J. Soc. Toxicol. 2006, 90, 230-240. [CrossRef]

29. Balakrishnan, B.; Thorstensen, E.B.; Ponnampalam, A.P.; Mitchell, M.D. Transplacental transfer and biotransformation of genistein in human placenta. Placenta 2010, 31, 506-511. [CrossRef]

30. Sun, F.; Kang, L.; Xiang, X.; Li, H.; Luo, X.; Luo, R.; Lu, C.; Peng, X. Recent advances and progress in the detection of bisphenol A. Anal. Bioanal. Chem. 2016, 408, 6913-6927. [CrossRef]

31. Schonfelder, G.; Wittfoht, W.; Hopp, H.; Talsness, C.E.; Paul, M.; Chahoud, I. Parent bisphenol A accumulation in the human maternal-fetal-placental unit. Environ. Health Perspect. 2002, 110, A703-A707. [CrossRef]

32. Yamada, H.; Furuta, I.; Kato, E.H.; Kataoka, S.; Usuki, Y.; Kobashi, G.; Sata, F.; Kishi, R.; Fujimoto, S. Maternal serum and amniotic fluid bisphenol A concentrations in the early second trimester. Reprod. Toxicol. 2002, 16, 735-739. [CrossRef]

33. Ikezuki, Y.; Tsutsumi, O.; Takai, Y.; Kamei, Y.; Taketani, Y. Determination of bisphenol A concentrations in human biological fluids reveals significant early prenatal exposure. Hum. Reprod. (Oxf. Engl.) 2002, 17, 2839-2841. [CrossRef] [PubMed]

34. Jalal, N.; Surendranath, A.R.; Pathak, J.L.; Yu, S.; Chung, C.Y. Bisphenol A (BPA) the mighty and the mutagenic. Toxicol. Rep. 2018, 5, 76-84. [CrossRef] [PubMed]

35. Foster, W.; Chan, S.; Platt, L.; Hughes, C. Detection of endocrine disrupting chemicals in samples of second trimester human amniotic fluid. J. Clin. Endocrinol. Metab. 2000, 85, 2954-2957. [CrossRef]

36. Koepke, R.; Warner, M.; Petreas, M.; Cabria, A.; Danis, R.; Hernandez-Avila, M.; Eskenazi, B. Serum DDT and DDE levels in pregnant women of Chiapas, Mexico. Arch. Environ. Health 2004, 59, 559-565. [CrossRef]

37. Hines, E.P.; Calafat, A.M.; Silva, M.J.; Mendola, P.; Fenton, S.E. Concentrations of phthalate metabolites in milk, urine, saliva, and Serum of lactating North Carolina women. Environ. Health Perspect. 2009, 117, 86-92. [CrossRef]

38. Arbuckle, T.E.; Davis, K.; Marro, L.; Fisher, M.; Legrand, M.; LeBlanc, A.; Gaudreau, E.; Foster, W.G.; Choeurng, V.; Fraser, W.D. Phthalate and bisphenol A exposure among pregnant women in Canada-results from the MIREC study. Environ. Int. 2014, 68, 55-65. [CrossRef]

39. Almeida, C.; Nogueira, J.M.F. Determination of steroid sex hormones in water and urine matrices by stir barsorptive extraction and liquid chromatography with diode array detection. J. Pharm. Biomed. 2006, 41, 1303-1311. [CrossRef]

40. Foster, W.G.; Chan, S.; Platt, L.; Hughes, C.L.J. Detection of phytoestrogens in samples of second trimester human amniotic fluid. Toxicol. Lett. 2002, 129, 199-205. [CrossRef]

41. Fleck, S.C.; Churchwell, M.I.; Doerge, D.R.; Teeguarden, J.G. Urine and serum biomonitoring of exposure to environmental estrogens II: Soyisoflavones and zearalenone in pregnant women. Food Chem. Toxicol. Int. J. Publ. Br. Biol. Res. Assoc. 2016, 95, 19-27. [CrossRef]

42. Geens, T.; Aerts, D.; Berthot, C.; Bourguignon, J.; Goeyens, L.; Lecomte, P.; Maghuin-Rogister, G.; Pironnet, A.; Pussemier, L.; Scippo, M.; et al. A review of dietary and non-dietary exposure to bisphenol-A. Food Chem. Toxicol. 2012, 50, 3725-3740. [CrossRef] [PubMed]

43. Hartle, J.C.; Navas-Acien, A.; Lawrence, R.S. The consumption of canned food and beverages and urinary Bisphenol A concentrations in NHANES 2003-2008. Environ. Res. 2016, 150, 375-382. [CrossRef] [PubMed]

44. Ellahi, M.; Rashid, M.U. The Toxic Effects BPA on Fetuses, Infants, and Children. Intech Open 2017.

45. Morck, T.J.; Sorda, G.; Bechi, N.; Rasmussen, B.S.; Nielsen, J.B.; Ietta, F.; Rytting, E.; Mathiesen, L.; Paulesu, L. Placental transport and in vitro effects of Bisphenol A. Reprod. Toxicol. 2010, 30, 131-137. [CrossRef] [PubMed]

46. Ponniah, M.; Billett, E.E.; De Girolamo, L.A. Bisphenol A increases BeWo trophoblast survival in stress-induced paradigms through regulation of oxidative stress and apoptosis. Chem. Res. Toxicol. 2015, 28, 1693-1703. [CrossRef]

47. Chu, P.; Yang, Z.; Huang, H.; Chang, A.; Cheng, Y.; Wu, G.; Lan, H. Low-dose bisphenol A activates the ERK signaling pathway and attenuates steroidogenic gene expression in human placental cells. Biol. Reprod. 2018, 98, 250-258. [CrossRef] 
48. Ye, Y.; Tang, Y.; Xiong, Y.; Feng, L.; Li, X. Bisphenol A exposure alters placentation and causes preeclampsia-like features in pregnant mice involved in reprogramming of DNA methylation of WNT2. FASEB J. Off. Publ. Fed. Am. Soc. Exp. Biol. 2019, 33, 2732-2742. [CrossRef]

49. Groff, T. Bisphenol A: Invisible pollution. Curr. Opin. Pediatr. 2010, 22, 524-529. [CrossRef]

50. Benachour, N.; Aris, A. Toxic effects of low doses of Bisphenol-A on human placental cells. Toxicol. Appl. Pharmacol. 2009, 241, 322-328. [CrossRef]

51. Narciso, L.; Ietta, F.; Romagnoli, R.; Paulesu, L.; Mantovani, A.; Tait, S. Effects of Bisphenol A on endogenous retroviral envelopes expression and trophoblast fusion in BeWo cells. Reprod. Toxicol. 2019, 89, 35-44. [CrossRef]

52. Paulesu, L.; Rao, C.V.; Ietta, F.; Pietropolli, A.; Ticconi, C. hCG and Its Disruption by Environmental Contaminants during Human Pregnancy. Int. J. Mol. Sci. 2018, 19, 914. [CrossRef] [PubMed]

53. Srakovsky, R.S.; Schantz, S.L. Impacts of bisphenol A (BPA) and exposures on epigenetic outcomes in the human placenta. Environ. Epigenet. 2018, 4, dvy022.

54. Montrose, L.; Padmanabhan, V.; Goodrich, J.M.; Domino, S.E.; Treadwell, M.C.; Meeker, J.D.; Watkins, D.J.; Dolinoy, D.C. Maternal levels of endocrine disrupting chemicals in the first trimester ofpregnancy are associated with infant cord blood DNA methylation. Epigenetics 2018, 13, 301-309. [CrossRef] [PubMed]

55. Muller, J.E.; Meyer, N.; Santamaria, C.G.; Schumacher, A.; Luque, E.H.; Zenclussen, M.L.; Rodriguez, H.A.; Zenclussen, A.C. Bisphenol A exposure during early pregnancy impairs uterine spiral artery remodeling and provokes intrauterine growth restriction in mice. Sci. Rep. 2018, 8, 9196. [CrossRef] [PubMed]

56. Timms, B.G.; Howdeshell, K.L.; Barton, L.; Bradley, S. Estrogenic chemicals in plastic and oral contraceptives disrupt development of the fetal mouse prostate and urethra. Biol. Reprod. 2005, 102, 7014-7019. [CrossRef] [PubMed]

57. Arase, S.; Ishii, K.; Igarashi, K.; Aisaki, K.; Yoshio, Y.; Matsushima, A.; Shimohigashi, Y.; Arima, K.; Kanno, J.; Sugimura, Y. Endocrine disrupter bisphenol A increases in situ estrogen production in the mouse urogenital sinus. Biol. Reprod. 2011, 84, 734-742. [CrossRef]

58. vom Saal, F.S.; Timms, B.G.; Montano, M.M.; Palanza, P.; Thayer, K.A.; Nagel, S.C.; Dhar, M.D.; Ganjam, V.K.; Parmigiani, S.; Welshons, W.V. Prostate enlargement in mice due to fetal exposure to low doses of estradiol or diethylstilbestrol and opposite effects at high doses. Proc. Natl. Acad. Sci. USA 1997, 94, 2056-2061. [CrossRef]

59. Shelnutt, S.; Kind, J.; Allaben, W. Bisphenol A: Update on newly developed data and how they address NTP's 2008finding of "Some Concern". Food Chem. Toxicol. Int. J. Publ. Br. Ind. Biol. Res. Assoc. 2013, 57, 284-295. [CrossRef]

60. Kolla, S.; Morcos, M.; Martin, B.; Vandenberg, L.N. Low dose bisphenol S or ethinyl estradiol exposures during the perinatal period alter female mouse mammary gland development. Reprod. Toxicol. 2018, 78, 50-59. [CrossRef]

61. Menone, M.L.; Aizpún de Moreno, J.E.; Moreno, V.J.; Lanfranchi, A.L.; Metcalfe, T.L.; Metcalfe, C.D. Organochlorine Pesticides and PCBs in a Southern Atlantic Coastal Lagoon Watershed, Argentina. Arch. Environ. Con. Tox. 2001, 40, 355-362.

62. Fair, P.A.; White, N.D.; Wolf, B.; Arnott, S.A.; Kannan, K.; Karthikraj, R.; Vena, J.E. Persistent organic pollutants in fish from Charleston Harbor and tributaries, South Carolina, United States: A risk assessment. Environ. Res. 2018, 167, 598-613. [CrossRef] [PubMed]

63. Jayaraj, R.; Megha, P.; Sreedev, P. Organochlorine pesticides, their toxic effects on living organisms and their fatein the environment. Interdiscip. Toxicol. 2016, 9, 90-100. [CrossRef] [PubMed]

64. Bandiera, S.M.; Torok, S.M.; Letcher, R.J.; Norstrom, R.J. Immunoquantitation of cytochromes P450 1A and P450 2B and comparison with chlorinated hydrocarbon levels in archived polar bear liver samples. Chemosphere 1997, 34, 1469-1479. [CrossRef]

65. Docea, A.O.; Vassilopoulou, L.; Fragou, D.; Arsene, A.L.; Fenga, C.; Kovatsi, L.; Petrakis, D.; Rakitskii, V.N.; Nosyrev, A.E.; Izotov, B.N.; et al. CYP polymorphisms and pathological conditions related to chronic exposure to organochlorine pesticides. Toxicol. Rep. 2017, 4, 335-341. [CrossRef]

66. Li, Y.; Millikan, R.C.; Bell, D.A.; Cui, L.; Tse, C.J.; Newman, B.; Conway, K. Polychlorinated biphenyls, cytochrome P450 1A1 (CYP1A1) polymorphisms, and breast cancer risk among African American women and white women in North Carolina: A population-based case-control study. Breast Cancer Res. BCR 2005, 7, R12-R18. [CrossRef] 
67. Mrema, E.J.; Rubino, F.M.; Brambilla, G.; Moretto, A.; Tsatsakis, A.M.; Colosio, C. Persistent organochlorinated pesticides and mechanisms of their toxicity. Toxicology 2013, 307, 74-88. [CrossRef]

68. Lopez-Espinosa, M.J.; Granada, A.; Carreno, J. Organochlorine Pesticides in Placentas from Southern Spain and Some Related Factors. Placenta 2007, 28, 631-638. [CrossRef]

69. Kumar, S. Occupational exposure associated with reproductive dysfunction. J. Occup. Health 2004, 46, 1-19. [CrossRef]

70. Anand, M.; Agarwal, P.; Singh, L. Persistent organochlorine pesticides and oxidant/antioxidant status in the placental tissue of the women with full-term and pre-term deliveries. Toxicol. Res. 2015, 4, 326-332. [CrossRef]

71. Anand, M.; Singh, L.; Agarwal, P.; Saroj, R.; Taneja, A. Pesticides exposure through environment and risk of pre-term birth: A study from Agra city. Drug Chem. Toxicol. 2019, 42, 471-477. [CrossRef]

72. Pathak, R.; Mustafa, M.; Ahmed, R.S.; Tripathi, A.K.; Guleria, K.; Banerjee, B.D. Association between recurrent miscarriages and organochlorine pesticide levels. Clin. Biochem. 2010, 43, 131-135. [CrossRef] [PubMed]

73. Muller, M.H.B.; Polder, A.; Brynildsrud, O.B.; Gronnestad, R.; Karimi, M.; Lie, E.; Manyilizu, W.B.; Mdegela, R.H.; Mokiti, F.; Murtadha, M.; et al. Prenatal exposure to persistent organic pollutants in Northern Tanzania and their distribution between breast milk, maternal blood, placenta and cord blood. Environ. Res. 2019, 170, 433-442. [CrossRef] [PubMed]

74. Kim, S.; Cho, Y.H.; Lee, I.; Kim, W.; Won, S.; Ku, J.; Moon, H.; Park, J.; Kim, S.; Choi, G.; et al. Prenatal exposure to persistent organic pollutants and methylation of LINE-1 and imprinted genes in placenta: A CHECK cohort study. Environ. Int. 2018, 119, 398-406. [CrossRef] [PubMed]

75. Dewan, P.; Jain, V.; Gupta, P.; Banerjeeb, B.D. Organochlorine pesticide residues in maternal blood, cord blood, placenta, and breastmilk and their relation to birth size. Chemosphere 2013, 90, 1704-1710. [CrossRef]

76. Freire, C.; Lopez-Espinosa, M.; Fernández, M. Prenatal exposure to organochlorine pesticides and TSH status in newborns from Southern Spain. Sci. Total Environ. 2011, 409, 3281-3287. [CrossRef]

77. Li, C.; Cheng, Y.; Tang, Q.; Lin, S.; Li, Y.; Hu, X.; Nian, J.; Gu, H.; Lu, Y.; Tang, H.; et al. The association between prenatal exposure to organochlorine pesticides and thyroid hormone levels in newborns in Yancheng, China. Environ. Res. 2014, 129, 47-51. [CrossRef]

78. Freire, C.; Koifman, R.J.; Sarcinelli, P.N.; Simoes Rosa, A.C.; Clapauch, R.; Koifman, S. Long-term exposure to organochlorine pesticides and thyroid status in adults in a heavily contaminated area in Brazil. Environ. Res. 2013, 127, 7-15. [CrossRef]

79. Bonde, J.P.; Flachs, E.M.; Rimborg, S.; Glazer, C.H.; Giwercman, A.; Ramlau-Hansen, C.H.; Hougaard, K.S.; Hoyer, B.B.; Haervig, K.K.; Petersen, S.B.; et al. The epidemiologic evidence linking prenatal and postnatal exposure to endocrine disrupting chemicals with male reproductive disorders: A systematic review and meta-analysis. Hum. Reprod. Update 2016, 23, 104-125. [CrossRef]

80. Kumar, V.; Yadav, C.S.; Singh, S.; Goel, S.; Ahmed, R.S.; Gupta, S.; Grover, R.K.; Banerjee, B.D. CYP 1A1 polymorphism and organochlorine pesticides levels in the etiology of prostate cancer. Chemosphere 2010, 81, 464-468. [CrossRef]

81. Korach, K.S.; Metzler, M.; McLachlan, J.A. Estrogenic activity in vivo and in vitro of some diethylstilbestrol metabolitesand analogs. Proc. Natl. Acad. Sci. USA 1978, 75, 468-471. [CrossRef]

82. Herbst, A.L.; Ulfelder, H.; Poskanzer, D.C.; Longo, L.D. Adenocarcinoma of the vagina. Association of maternal stilbestrol therapy with tumor appearance in young women. Am. J. Obstet. Gynecol. 1999, 181, 1574-1575. [CrossRef]

83. Veurink, M.; Koster, M.; Berg, L.T.W.D. The history of DES, lessons to be learned. Pharm. World Sci. 2005, 27, 139-143. [CrossRef] [PubMed]

84. Colton, T.; Greenberg, E.R.; Noller, K.; Resseguie, L.; Van Bennekom, C.; Heeren, T.; Zhang, Y. Breast cancer in mothers prescribed diethylstilbestrol in pregnancy. Further follow-up. JAMA 1993, 269, 2096-2100. [CrossRef] [PubMed]

85. Bibbo, M.; Haenszel, W.M.; Wied, G.L.; Hubby, M.; Herbst, A.L. A twenty-five-year follow-up study of women exposed to diethylstilbestrol during pregnancy. N. Engl. J. Med. 1978, 298, 763-767. [CrossRef] [PubMed]

86. Greenberg, E.R.; Barnes, A.B.; Resseguie, L.; Barrett, J.A.; Burnside, S.; Lanza, L.L.; Neff, R.K.; Stevens, M.; Young, R.H.; Colton, T. Breast cancer in mothers given diethylstilbestrol in pregnancy. N. Engl. J. Med. 1984, 311, 1393-1398. [CrossRef] [PubMed] 
87. Titus-Ernstoff, L.; Hatch, E.E.; Hoover, R.N.; Palmer, J.; Greenberg, E.R.; Ricker, W.; Kaufman, R.; Noller, K.; Herbst, A.L.; Colton, T.; et al. Long-term cancer risk in women given diethylstilbestrol (DES) during pregnancy. Br. J. Cancer 2001, 84, 126-133. [CrossRef]

88. Yu, K.; Wang, R.; Li, M.; Sun, T.; Zhou, Y.; Li, Y.; Sun, L.; Zhang, B.; Lian, Z.; Xue, S.; et al. Melatonin Reduces Androgen Production and Upregulates Heme Oxygenase-1 Expression in Granulosa Cells from PCOS Patients with Hypoestrogenia and Hyperandrogenia. Oxid. Med. Cell. Longev. 2019, 2019, 13. [CrossRef]

89. Newbold, R.R.; Hanson, R.B.; Jefferson, W.N.; Bullock, B.C.; Haseman, J.; McLachlan, J.A. Increased tumors but uncompromised fertility in the female descendants of mice exposed developmentally to diethylstilbestrol. Carcinogenesis 1998, 19, 1655-1663. [CrossRef]

90. Newbold, R.R.; Padilla-Banks, E.; Jefferson, W.N. Adverse effects of the model environmental estrogen diethylstilbestrol are transmitted to subsequent generations. Endocrinology 2006, 147, S11-S17. [CrossRef]

91. Wilcox, A.J.; Baird, D.D.; Weinberg, C.R.; Hornsby, P.P.; Herbst, A.L. Fertility in men exposed prenatally to diethylstilbestrol. N. Engl. J. Med. 1995, 332, 1411-1416. [CrossRef]

92. Al Jishi, T.; Sergi, C. Current perspective of diethylstilbestrol (DES) exposure in mothers and offspring. Reprod. Toxicol. 2017, 71, 71-77. [CrossRef] [PubMed]

93. Newbold, R.R. Prenatal exposure to diethylstilbestrol (DES). Fertil. Steril. 2008, 89, e55-e56. [CrossRef] [PubMed]

94. Yamashita, S. Expression of estrogen-regulated genes during development in the mouse uterus exposed to diethylstilbestrol neonatally. Curr. Pharm. Des. 2006, 12, 1505-1520. [CrossRef] [PubMed]

95. Bhan, A.; Hussain, I.; Ansari, K.I.; Bobzean, S.A.M.; Perrotti, L.I.; Mandal, S.S. Histone methyltransferase EZH2 is transcriptionally induced by estradiol as well as estrogenic endocrine disruptors bisphenol-A and diethylstilbestrol. J. Mol. Biol. 2014, 426, 3426-3441. [CrossRef] [PubMed]

96. Singh, N.P.; Abbas, I.K.; Menard, M.; Singh, U.P.; Zhang, J.; Nagarkatti, P.; Nagarkatti, M. Exposure to diethylstilbestrol during pregnancy modulates microRNA expression profile in mothers and fetuses reflecting oncogenic and immunological changes. Mol. Pharmacol. 2015, 87, 842-854. [CrossRef] [PubMed]

97. Mikula, P.; Svobodova, Z.; Smutna, M. Phthalates: Toxicology and Food Safety-a Review. Czech J. Food Sci. 2005, 23, 217-223. [CrossRef]

98. Ito, R.; Seshimo, F.; Miura, N.; Kawaguchi, M.; Saito, K.; Nakazawa, H. Effect of sterilization process on the formation of mono(2-ethylhexyl) phthalate from di(2-ethylhexyl) phthalate. J. Pharm. Biomed. Anal. 2006, 41, 455-460. [CrossRef]

99. Zhao, Y.; Ao, H.; Chen, L.; Sottas, C.M.; Ge, R.; Li, L.; Zhang, Y. Mono-(2-ethylhexyl) phthalate affects the steroidogenesis in rat Leydig cells through provoking ROS perturbation. Toxicol. Int. J. Publ. Assoc. BIBRA 2012, 26, 950-955. [CrossRef]

100. Shoaito, H.; Petit, J.; Chissey, A.; Auzeil, N.; Guibourdenche, J.; Gil, S.; Laprevote, O.; Fournier, T.; Degrelle, S.A. The Role of Peroxisome Proliferator-Activated Receptor Gamma (PPAR gamma) in Mono (2-ethylhexyl) Phthalate (MEHP)-Mediated Cytotrophoblast Differentiation. Environ. Health Perspect. 2019, 127, 27003. [CrossRef]

101. Valinluck, V.; Tsai, H.; Rogstad, D.K.; Burdzy, A.; Bird, A.; Sowers, L.C. Oxidative damage to methyl-CpG sequences inhibits the binding of the methyl-CpG binding domain (MBD) of methyl-CpG binding protein 2 (MeCP2). Nucleic Acids Res. 2004, 32, 4100-4108. [CrossRef]

102. Gao, F.; Hu, W.; Li, Y.; Shen, H.; Hu, J. Mono-2-ethylhexyl phthalate inhibits human extravillous trophoblast invasion via the PPARgamma pathway. Toxicol. Appl. Pharm. 2017, 327, 23-29. [CrossRef] [PubMed]

103. Lemmon, M.A.; Schlessinger, J. Cell signaling by receptor tyrosine kinases. Cell 2010, 141, 1117-1134. [CrossRef] [PubMed]

104. Bass, K.E.; Morrish, D.; Roth, I.; Bhardwaj, D.; Taylor, R.; Zhou, Y.; Fisher, S.J. Human cytotrophoblast invasion is up-regulated by epidermal growth factor: Evidence that paracrine factors modify this process. Dev. Biol. 1994, 164, 550-561. [CrossRef] [PubMed]

105. Grindler, N.M.; Vanderlinden, L.; Karthikraj, R.; Kannan, K.; Teal, S.; Polotsky, A.J.; Powell, T.L.; Yang, I.V.; Jansson, T. Exposure to Phthalate, an Endocrine Disrupting Chemical, Alters the First Trimester Placental Methylome and Transcriptome in Women. Sci. Rep. 2018, 8, 6086. [CrossRef] [PubMed]

106. Zhang, Y.; Lin, L.; Cao, Y.; Chen, B.; Zheng, L.; Ge, R. Phthalate levels and low birth weight: A nested case-control study of Chinesenewborns. J. Pediatr. 2009, 155, 500-504. [CrossRef] 
107. Buck Louis, G.M.; Sundaram, R.; Sweeney, A.M.; Schisterman, E.F.; Maisog, J.; Kannan, K. Urinary bisphenol A, phthalates, and couple fecundity: The Longitudinal Investigation of Fertility and the Environment (LIFE) Study. Fertil. Steril. 2014, 101, 1359-1366. [CrossRef]

108. Toft, G.; Jonsson, B.A.G.; Lindh, C.H.; Jensen, T.K.; Hjollund, N.H.; Vested, A.; Bonde, J.P. Association between pregnancy loss and urinary phthalate levels around the time of conception. Environ. Health Perspect. 2012, 120, 458-463. [CrossRef]

109. Jukic, A.M.; Calafat, A.M.; McConnaughey, D.R.; Longnecker, M.P.; Hoppin, J.A.; Weinberg, C.R.; Wilcox, A.J.; Baird, D.D. Urinary Concentrations of Phthalate Metabolites and Bisphenol A and Associations with Follicular-Phase Length, Luteal-Phase Length, Fecundability, and Early Pregnancy Loss. Environ. Health Perspect. 2016, 124, 321-328. [CrossRef]

110. Petit, J.; Wakx, A.; Gil, S.; Fournier, T.; Auzeil, N.; Rat, P.; Laprevote, O. Lipidome-wide disturbances of human placental JEG-3cells by the presence of MEHP. Biochimie 2018, 149, 1-8. [CrossRef]

111. Philippat, C.; Heude, B.; Botton, J.; Alfaidy, N.; Calafat, A.M.; Slama, R. Prenatal Exposure to Select Phthalates and Phenols and Associations with Fetal and Placental Weight among Male Births in the EDEN Cohort (France). Environ. Health Perspect. 2019, 127, 17002. [CrossRef]

112. Kilcoyne, K.R.; Mitchell, R.T. Effect of environmental and pharmaceutical exposures on fetal testis development and function: A systematic review of human experimental data. Hum. Reprod. Update 2019, 25, 397-421. [CrossRef] [PubMed]

113. Jensen, M.S.; Anand-Ivell, R.; Norgaard-Pedersen, B.; Jonsson, B.A.G.; Bonde, J.P.; Hougaard, D.M.; Cohen, A.; Lindh, C.H.; Ivell, R.; Toft, G. Amniotic fluid phthalate levels and male fetal gonad function. Epidemiology (Camb. Mass.) 2015, 26, 91-99. [CrossRef] [PubMed]

114. Kuhnle, G.G.C.; Dell'Aquila, C.; Aspinall, S.M.; Runswick, S.A.; Mulligan, A.A.; Bingham, S.A. Phytoestrogen content of beverages, nuts, seeds, and oils. J. Agric. Food Chem. 2008, 56, 7311-7315. [CrossRef] [PubMed]

115. Tucak, M.; Horvat, D.; Cupic, T.; Krizmanic, G.; Tomas, V.; Ravlic, M.; Popovic, S. Forage Legumes as Sources of Bioactive Phytoestrogens for Use in Pharmaceutics: A Review. Curr. Pharm. Biotechnol. 2018, 19, 537-544. [CrossRef] [PubMed]

116. Bukovsky, A.; Caudle, M.R.; Cekanova, M.; Fernando, R.I.; Wimalasena, J.; Foster, J.S.; Henley, D.C.; Elder, R.F. Placental expression of estrogen receptor beta and its hormone binding variant-comparison with estrogen receptor alpha and a role for estrogen receptors in asymmetric division and differentiation of estrogen-dependent cells. Reprod. Biol. Endocrinol. 2003, 1, 36. [CrossRef] [PubMed]

117. Tang, Z.; Zhang, R.; Lian, Z.; Deng, S.; Yu, K. Estrogen-Receptor Expression and Function in Female Reproductive Disease. Cells 2019, 8, 1123. [CrossRef] [PubMed]

118. Jia, M.; Dahlman-Wright, K.; Gustafsson, J. Estrogen receptor alpha and beta in health and disease. Best Pract. Research. Clin. Endocrinol. Metab. 2015, 29, 557-568. [CrossRef]

119. Awobajo, F.; Abdul, M.; Aminu, B.; Medobi, E. Alteration to PGF and IGF-1, signalled the adverse growth of the foetus and placenta in a genistein exposed pregnancy in experimental rats. Endocr. Abstr. 2018, 59, 192. [CrossRef]

120. Jeschke, U.; Briese, V.; Richter, D.; Bruer, G.; Plessow, D.; Waldschlager, J.; Mylonas, I.; Friese, K. Effects of phytoestrogens genistein and daidzein on production of human chorionicgonadotropin in term trophoblast cells in vitro. Gynecol. Endocrinol. Off. J. Int. Soc. Gynecol. Endocrinol. 2005, 21, 180-184. [CrossRef]

(C) 2020 by the authors. Licensee MDPI, Basel, Switzerland. This article is an open access article distributed under the terms and conditions of the Creative Commons Attribution (CC BY) license (http://creativecommons.org/licenses/by/4.0/). 